\title{
DEVELOPING INQUIRY-BASED PRACTICE EQUIPMENT OF HEAT CONDUCTIVITY TO FOSTER THE STUDENTS' CRITICAL THINKING ABILITY
}

\author{
Ratna Agustini ${ }^{1}$, Agus Suyatna ${ }^{* 2}$ \\ ${ }^{1}$ State Junior High school 3 Blambangan Umpu, Way Kanan, Lampung, Indonesia \\ ${ }^{2}$ Department of Physics Education, Universitas Lampung, Lampung, Indonesia \\ *Correspondence address: asuyatna@yahoo.com
}

Accepted: October $7^{\text {th }}, 2017$. Approved: February $1^{\text {st }}, 2018$. Published: April $28^{\text {th }}, 2018$

\begin{abstract}
The purpose of this research is to develop inquiry-based practice equipment of heat conductivity to foster the students' critical thinking ability. The research method employed was research and development $(R \& D)$. The development model used was ADDIE (Analysis-Design-Development-ImplementationEvaluation) model. Validation of product development was done by science education experts. Field-testing was conducted to the seventh-grade students of State Junior High school 3 (SMP Negeri 3) Blambangan Umpu Way Kanan. The data collection was done through observation, questionnaires, and tests of the effectiveness of fostering students' critical thinking ability. Data analysis was done through paired sample T-Test and independent sample T-Test. The results showed that the inquiry-based practice equipment of heat conductivity was effective in fostering the students' critical thinking ability the value of N-gain 0.70 (high category). The equipment and its guides were considered interesting, practical, and useful by the students. So, it is concluded that the inquiry-based practice equipment of heat conductivity is able to foster the students' critical thinking ability.
\end{abstract}

(C) 2018 Physics Education, UIN Raden Intan, Lampung, Indonesia

Keywords: critical thinking, inquiry, heat conductivity, practice equipment

\section{INTRODUCTION}

Natural Science is a science that studies certain phenomena systematically (Inzanah, Ibrahim, \& Widodo, 2014). Science learning is application-oriented to develop learning ability, thinking ability, curiosity, and caring and responsible attitude to the social and natural environment (Nisa', Sudarmin, \& Samini, 2015). Natural Science is needed to build students' skills in solving a problem and caring the surrounding environment (Arisman \& Permanasari, 2015).

The process of science learning can be felt directly by students in developing their competence to understand the natural surroundings in a scientific way. But today science is only a product, rigid, and legal theory. As a result, the attitude, the process in everyday life and the application are untouched (Inzanah et al., 2014). Natural Science is not enough to be learned only through explanation and listening, but also by understanding the material and concepts by doing activities to find the concepts (Abdurrahman, Saregar, \& Umam, 2018; Anwar, 2017; Dewi, 2016; Saregar, Marlina, \& Kholid, 2017).

One of the learning activities in science learning that apply the scientific method in learning is practicum activity (Maulida \& Kusumaningtyas, 2017). Running the lab course must be supported by the existence of adequate practicum equipment.

Based on the observation at State Junior High School 3 Blambangan Umpu, Way Kanan, there were still many practicum equipments that was not effectively used, for example, the heat conductivity equipment that can only be used to investigate the metal that transfers heat but cannot use to determine the rate of heat transfer. Consequently, it cannot encourage students' critical thinking 
during the practicum. While it is known that the ability to think critically is a competency that must be mastered by students (Latifah, 2015).

Based on preliminary study for the teacher in the analysis phase, the result of the questionnaire for the teachers' need analysis are: a) the presence of equipment for heat transfer material especially conductive heat transfer but rarely used because of difficulties in its application, b) students were less enthusiastic during learning, c) it needs a simple heat conductivity transfer practicum equipment that is easy to use.

The questionnaire results of the students' need analysis were taken from 30 students of seventh of State Junior High School 3 Blambangan Umpu, Way Kanan in the 2016 academic year that have studied the heat transfer. More than $90 \%$ of the students need an alternative learning media in the form of equipment that is simple and interesting to study the concept of heat conductive transfer so that the learning process can stimulate the students' critical thinking ability.

In the $21^{\text {st }}$ century, critical thinking learning needs to be prepared so that graduates can compete in filling the job market, so critical thinking becomes one of the skills that need to be developed in the educational process (Lastriningsih, 2017). Critical thinking is the ability and process involved in making a rational decision and is an attitude that is used by someone to judge something (Diana Putri \& Djamas, 2017). Skills in analyzing arguments, solving problems, evaluating, and making conclusions are part of critical thinking (Nuriyatin \& Hartono, 2016). For this purpose, education tries to help students learn to organize and construct opinions, to formulate problems, to develop hypotheses, and to seek their evidence to foster students' critical thinking skills (Bell, Urhahne, \& Schanze, 2013).

To equip the ability to think critically for students, it is necessary to have student- centered learning. Student-centered learning is inquiry-based learning, in which the students are required to play an active role in learning (Asyhari \& Hartati, 2015). Inquiry learning involves students in formulating scientific questions, proposing hypotheses, collecting and analyzing the results of investigations, reasoning on phenomena, and communicating results to teachers and other students (Abdurrahman, 2017). Student-centered learning can be done to stimulate students' critical thinking skills, one of them through practicum activities. In practice, it is necessary to have practicum equipment that can foster the students' learning activities and provide a real experience and interest the students so that learning activities are not boring and all the senses of students can be activated. Based on these conditions, the researcher developed practicum equipment of heat conductivity through inquiry-based worksheet as a guide.

To develop relevant equipment related to heat transfer material, a research was conducted by Rokhimi and Pujayanto on Conductivity Rate Learning Instrument (Rokhimi \& Pujayanto, 2015). The differences of this research with previous research are, that the equipment is equipped with inquiry-based student worksheet to foster the students' critical thinking ability. Based on this, then researchers consider this research is important to be done.

\section{METHOD}

The method used by researchers was research and development. The development model used was ADDIE model (Analysis -Design - Development Implementation-Evaluation). This research resulted in the development of practicum equipment in the form of heat conductivity equipment to foster students' critical thinking ability on the concept of heat transfer. The developed heat 
conductivity equipment is complemented by inquiry-based student worksheet.

The product of the initial development is called prototype 1 and was revised to meet the criteria of the validators.

The first testing done was expert validation. This testing was conducted to validate the feasibility of the product so it can be known whether the developed product was feasible to use. Expert validation was carried out by three experts in the field of science education. The validation tests covered the appropriateness of the product with the learning objectives and the effectiveness of the equipment. A validation test was repeatedly done until the product of development was declared as valid. The one-on-one test was performed by peers as users of the heat conductivity equipment to assess the easiness and usefulness of the tools in assisting the learning process.

The assessment was done by teachers as practitioners who taught in the seventh grade of Junior High School. This process was done to determine the practicability of heat conductivity equipment and to check the error of writing on the student worksheet. Furthermore, a small group testing was also conducted to find out the product's usability in learning. The results obtained from this small group testing were used to adjust the use of the product in the learning. The evaluation results obtained from the testing were used for product revision so that it can be feasible to use.

Product development results that have been feasible were field-tested to 60 students of seventh-grade class VII A and VII B of the State Junior High School 3 Blambangan Umpu Way kanan. Data collecting techniques were observation, questionnaires, and tests of students' critical thinking skills. The data analysis was done by paired sample T-Test and independent sample T-Test. While, fieldtesting was conducted using a pretestposttest control group experimental design. The experiments on the implementation of conductivity practicum equipment were conducted on two classes. First class was taught by the researchers and second class by other teachers. A pretest was done before the implementation and post-test were done after. The tests' questions are designed to measure students' critical thinking skills. The research design used is described in Table 1.

Table 1. Pre-test and post-test group design

\begin{tabular}{|c|c|c|c|}
\hline Group & Pre-test & Treatment & Post-test \\
\hline VII A & $\mathrm{O}_{1}$ & $\mathrm{X}_{1}$ & $\mathrm{O}_{2}$ \\
\hline VII B & $\mathrm{O}_{1}$ & $\mathrm{X}_{2}$ & $\mathrm{O}_{2}$ \\
\hline
\end{tabular}

Explanation:

$\mathrm{O}_{1}=$ Pre-test beforetreatments.

$\mathrm{O}_{2}=$ post-test after treatments.

$\mathrm{X}_{1}=$ learning activity using the developed heat conductivity equipment in the heat transfer material. The researcher acts as the teacher.

$\mathrm{X}_{2}=$ learning activity using the developed heat conductivity equipment in the heat transfer material by the actual teacher.

Treatments were given to the first and second experimental classes. They were given the same treatment using heat conductivity equipment as the result of the development. The first experimental class was taught by the researcher and the second experimental class was taught by the native teacher of the school.

\section{RESULT AND DISCUSSION}

The equipment was made using simple materials. It was designed to compare the ability of three different metals in terms of length and diameter in transferring heat, and also to determine the rate of heat transfer of each metal. The source of heat was three electrical solders, the position of thermometers in each metal can be manipulated so that the change in temperature can be observed. The developed product was accompanied by inquiry-based student worksheet. The critical thinking ability can be 
measured by the result of pre-test and posttest. The tests' specification was constructed based on the students' ability in giving argument, deduction, evaluation based on the information gained and the process of critical thinking is implementing the result.

The final product had been revised several times through the advisors, expert validation, and peer-assessment toward the usefulness, feasibility, and the practicality of the product. The display of the product viewed from different angles can be seen in the following figures:

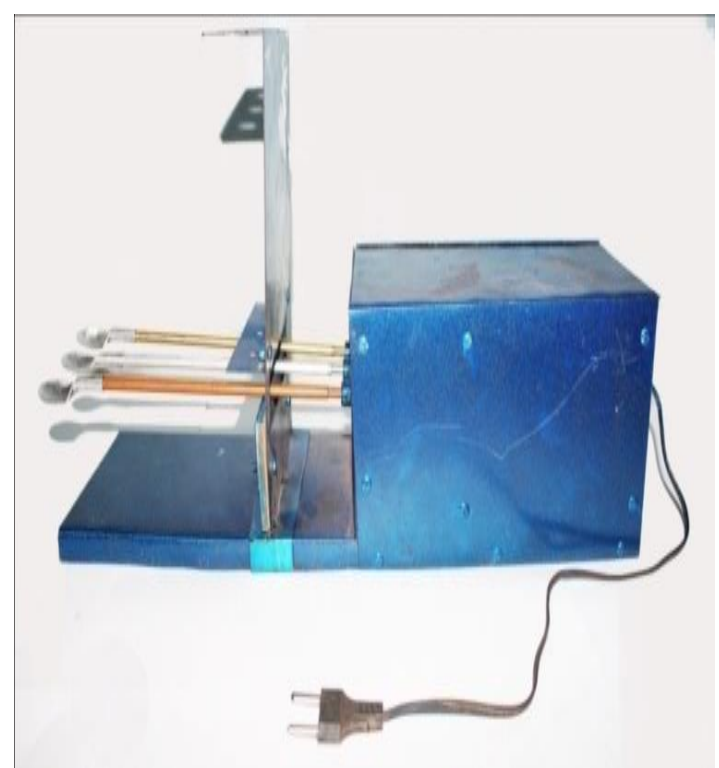

Figure 1. Side-view of the product

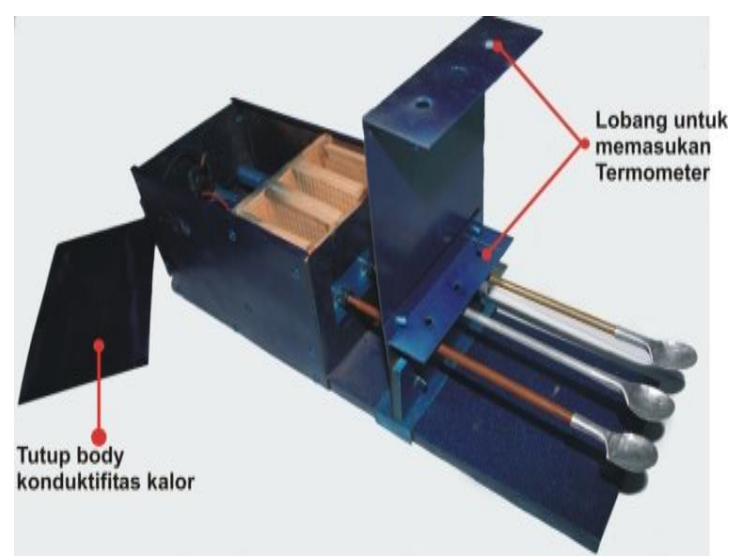

Figure 2. Top-view of the product with an opened case

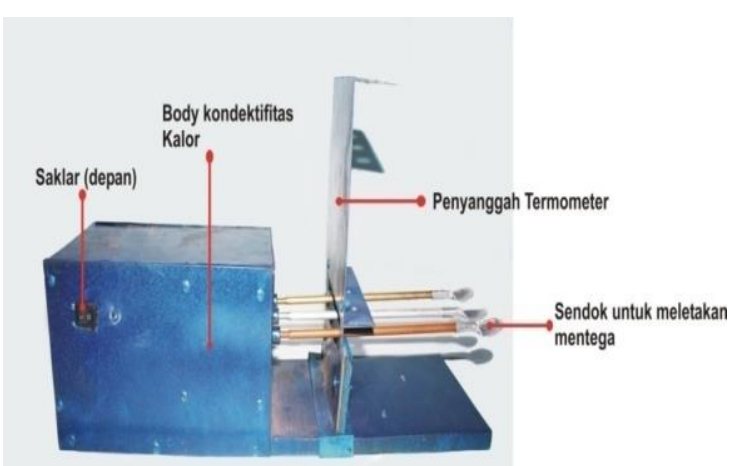

Figure 3. Side-view of the product

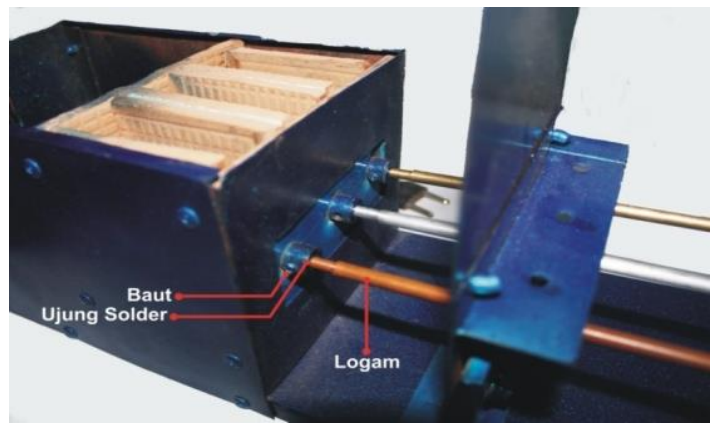

Figure 4. Metal connector and the box

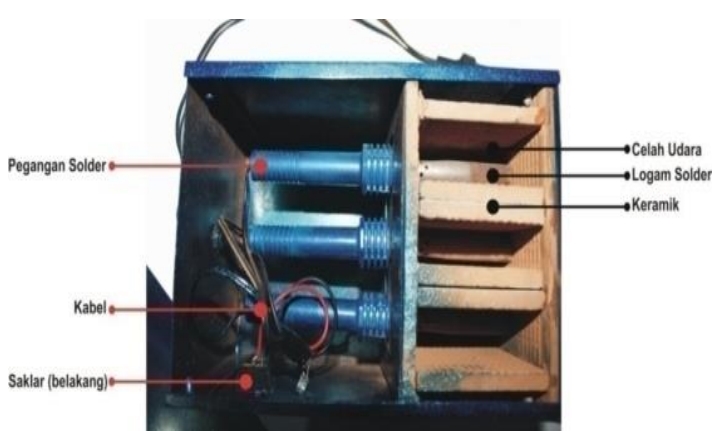

Figure 5. Top-view of the product

Table 2. Description of the parts of the product

\begin{tabular}{ll}
\hline Component & \multicolumn{1}{c}{ Description } \\
\hline Metal Solder & $\begin{array}{l}\text { Three 60 Watt solders } \\
\text { arranged in a row but } \\
\text { given a gap. } \\
\text { To prevent over-heating. }\end{array}$ \\
Vent
\end{tabular}

Ceramic To prevent the heat to spread to the side of the box.

Switch To connect the electric current.

Wire Distributing power source to solder.

Tip of metal To connect metal for solder observations 


\begin{tabular}{ll}
\hline Component & \multicolumn{1}{c}{ Description } \\
\hline Bolt & $\begin{array}{l}\text { Bolt to tighten metal } \\
\text { position attached to the } \\
\text { tip of solder. } \\
\text { Spoon }\end{array}$ \\
& $\begin{array}{l}\text { Used to put butter for heat } \\
\text { indicator. If the heat } \\
\text { spreads to the side, the } \\
\text { butter will melt, because } \\
\text { butter is very sensitive to } \\
\text { heat. } \\
\text { Thermometer make it easier to } \\
\text { molder }\end{array}$ \\
& $\begin{array}{l}\text { measure the temperature } \\
\text { change between the metal } \\
\text { attached to the solder } \\
\text { with metal close to the } \\
\text { spoon. }\end{array}$ \\
\hline
\end{tabular}

Product development results then further tested before being implemented. The first experimental tool test is done by experts, then the individual, a then small group to know the application of product development in learning. The results of this small group testing were used to find out the students' responses to the use of the product.

The initial product validation by a science expert to assess the suitability of the tool development with the objective the data is shown in Table 3

Table 3. The testing result from the expert of construction, the expert of heat conductivity equipment, and the content of practicum guide

\begin{tabular}{lcccc}
\hline \multicolumn{1}{c}{ Type of Validation } & Validator 1 & Validator 2 & Validator 3 & Average \\
\hline The construction of the product & 3,27 & 3,27 & 3,09 & 3,21 \\
The materials of the product & 3,09 & 3,45 & 3,00 & 3,18 \\
The construction of the worksheet & 3,26 & 3,63, & 2,95 & 3,28 \\
The content of worksheet & 3,13 & 3,67 & 2,93 & 3,24 \\
\hline
\end{tabular}

Table 4. Conversion of the assessment Score into Statement

\begin{tabular}{cc}
\hline Score & Statement \\
\hline $3,25<\bar{\chi} \leq 4,00$ & Very Good \\
$2,50<\bar{\chi} \leq 3,25$ & Good \\
$1,75<\bar{\chi} \leq 2,50$ & Poor \\
$1,00<\bar{\chi} \leq 1,75$ & Very poor
\end{tabular}

Based on Table 3 and Table 4, can be concluded that for construct, material of product, and students worksheet is "Good criterion". The practitioners' validation connects to construct and material product also student's worksheet. Through peer to peer test, scoring from practitioners by two teachers who teach science in Junior High School shown in Table 5 as users. Small group product test is shown in Table 6 .

Table 5. Small group test result of construction and experts test of heat conductivity product and practicum content guide

\begin{tabular}{lcc}
\hline \multicolumn{1}{c}{ Type of validation } & $\begin{array}{c}\text { Average score from the } \\
\text { first ad the second teacher }\end{array}$ & Kriteria \\
\hline The construction of the product & 3,50 & Very Good \\
The materials of the product & 3,50 & Very Good \\
The construction of the worksheet & 3,00 & Good \\
The content of worksheet & 3,10 & Good \\
\hline
\end{tabular}

Table 6. The result of small-group testing

\begin{tabular}{ccccc}
\hline \multirow{2}{*}{ Aspects } & \multicolumn{2}{c}{ Heat conductivity equipment } & \multicolumn{2}{c}{ Practicum guide } \\
\cline { 2 - 5 } & Score & Criteria & Score & Criteria \\
\hline Attractiveness & 88 & Very attractive & 84 & Very attractive \\
Practicallity & 85 & Very practical & 89 & Very practical \\
Usefulness & 97 & Very usefull & 86 & Very usefull \\
\hline Total & 90 & & 86 & \\
\hline
\end{tabular}


Based on the results of small group testing on attractiveness, practicality, and usefulness of the developed product, it was obtained the score $90 \%$ and $86 \%$ on the heat conductivity equipment and the practicum guide. This data shows students' responses that provide excellent product grades to be applicable in learning.

In relation to attractiveness, practicality, and usefulness, the test was conducted to 60 students of Blambangan Umpu State Junior High School of VII A and VII B class shown in Table 7.

Table 7. The result of attractiveness, practicality, and usefulness of the developed product.

\begin{tabular}{ccccc}
\hline \multirow{2}{*}{ Aspects } & \multicolumn{2}{c}{$\begin{array}{c}\text { Heat } \\
\text { conductivity } \\
\text { equipment }\end{array}$} & \multicolumn{2}{c}{$\begin{array}{c}\text { Practicum } \\
\text { guide }\end{array}$} \\
\cline { 2 - 5 } & VII A & VII B & VII A & VII B \\
\hline Attractiveness & 88 & 87 & 81 & 82 \\
Practicallity & 71 & 75 & 74 & 88 \\
Usefulness & 95 & 89 & 82 & 92 \\
Total & 78 & 87 & 75 & 89 \\
\hline
\end{tabular}

Based on the data, the result of attractiveness, practicality, and usefulness according to the student's responses reached an average score of $77 \%$ with good criterion. Practical guide in the form of worksheet got $88 \%$ of student appraisal with the very good criterion. This is relevant with the opinion that stated that the practicum equipment accompanied by practicum guide hold some benefits such as: clarify the information so that there is an increase in learning outcomes, improve motivation to learn, interact directly with the students environment in its own way based on the ability and interest, with the limitations of the five senses, time and space and to provide the same experience for all students as well as the emergence of direct interaction with teachers, community, and even the environment.

Adegoke \& Chukwunenye states that hands-on experiments are preferred because they bring students directly to real-life phenomena and can train students' creativity (Adegoke \& Chukwunenye, 2013). Meanwhile, according to Popescu $\&$ Morgan, the delivery of Physics learning should be as much as possible to bring children into real life, because by using real situations, students will find physics more relevant so that they will be more involved and motivated in class (Popescu \& Morgan, 2007).

The effectiveness test in the use of heat conductivity practicum equipment based on the cognitive aspect of students in class VII A and VII B at State Junior High School 3 Blambangan Umpu, Way Kanan was determined based on normalized $\mathrm{N}$ gain by comparing the score of pretest and posttest done by the students

The effectiveness test was conducted on the science course of heat transfer lesson which was conducted through written test. The tests were given in the form of 6 essay questions and each correct answer worth 10 points. The $\mathrm{N}$-gain value obtained from the two treatment classes was expected to obtain the same score. Based on the research results, the data obtained are shown in Table 8.

Table 8. the result of critical thinking tests

\begin{tabular}{ccc}
\hline Type of test & Class VII & Class \\
& A & VII B \\
\hline Pre-Test & 35.419 & 34.310 \\
Post-Test & 81.548 & 79.310 \\
Normalized N-gain & 0.706 & 0.700 \\
\hline
\end{tabular}

It was expected that the result of the effectiveness test to achieve a comparable effectiveness score between the two experimental classes. A statistical test was needed to prove the hypothesis that the $\mathrm{N}$ gain increase was the effect of using the developed heat conductivity equipment. Data analysis was done based on $\mathrm{N}$-gain result obtained from field testing in two classes with the different teacher, but the process of learning was using the same lesson plans.

The average result of the $\mathrm{N}$-gain value of class VIIA and VIIB of State Junior High School 3 Blambangan Umpu was 
0.706 and 0.700 respectively. $\mathrm{N}$-gain was> 0.7 which means a high level of effectiveness in fostering students' critical thinking skills through the use of heat conductivity tools in science lessons existed.

Assessment of effectiveness in the use of the developed equipment was done in order to increase the ability to think critically of the students in the two research classes. A t-test was done using a normal and homogenous data. Tests on the $\mathrm{N}$-gain aim to determine that there is no difference in $\mathrm{N}$-gain values in the two classes even though they are taught by different teachers. The results of the statistical analysis test are presented in Table 9.

Table 9. The N-gain value of the students of class VIIA and VIIB of State Junior High school Blambangan Umpu

\begin{tabular}{ccccc}
\hline \multirow{3}{*}{ Test } & \multicolumn{3}{c}{ t-test } & Result \\
\cline { 2 - 4 } & $\begin{array}{c}\mathbf{t}- \\
\text { critical }\end{array}$ & t-table & Sig & \\
\hline N-gain 0.107 & 0.678 & 0.915 & $\begin{array}{c}\mathrm{t}_{\text {value }}<\mathrm{t}_{\text {table }} \\
\text { Ho is } \\
\text { accepted }\end{array}$ \\
\hline
\end{tabular}

Based on the calculation, it was obtained sig value of 0.915 which is greater than $\alpha 5 \%$, which means $\mathrm{H}_{0}$ is accepted. This test proved that there was no difference of $\mathrm{N}$-gain value between class VIIA and VIIB that receive the treatment. The increase in $\mathrm{N}$-gain value was as the impact of the use of heat conductivity equipment in the practicum that was able to foster the students' critical thinking skills.

\section{CONCLUSION AND SUGGESTION Conclusion}

Heat conductivity equipment produced for the seventh-grade students on heat transfer material that can compare the heat conductivity capability of 3 different metal types, even the students were able to find the value of heat transfer rate of copper, aluminum, and brass. The equipment is equipped with an inquiry-based worksheet as a guide that can foster the students' critical thinking ability. The attractiveness, practicality and usefulness of heat conductivity equipment and the guide received excellent response from the students by $88 \%$ and $89 \%$.

The effectiveness of the developed product toward the students' critical thinking ability in class VII A and VII B in State Junior High School 3 Blambangan Umpu Way Kanan obtained the N-gain value of 0,700 . This shows a high effectiveness value. Thus, the heat conductivity equipment can work well to be utilized in learning by following procedures in accordance with the worksheet that has been prepared to foster the students' critical thinking ability.

\section{Suggestion}

The development of heat conductivity equipment is expected to be further researched in a wider range of functions, not only for heat transfer materials but also for temperature changes such as the length expand of a metal.

\section{REFERENCES}

Abdurrahman. (2017). Efektivitas dan Kendala Pembelajaran Sains Berbasis Inkuiri terhadap Capaian Dimensi Kognitif Siswa: Meta Analisis. Tadris: Jurnal Keguruan Dan Ilmu Tarbiyah, 2(1), 1-9. https://doi.org/https://doi.org/10.240 42/tadris.v2i1.1206

Abdurrahman, A., Saregar, A., \& Umam, R. (2018). The Effect of Feedback as Soft Scaffolding on Ongoing Assessment Toward The Quantum Physics Concept Mastery of The Prospective Physics Teachers. Jurnal Pendidikan IPA Indonesia, 7(1), 4147. https://doi.org/10.15294/jpii.v6i2.72 39

Adegoke, B. A., \& Chukwunenye, N. 
(2013). Improving Students' Learning Outcomes In Practical Physics, Which Is Better? Computer Simulated Experiment or Hands-On Experiment? Journal of Reserch \& Method in Education, 2(6), 18-26.

Anwar, C. (2017). The Effectiveness of Problem Based Learning Integrated With Islamic Values Based on ICT on Higher Order Thinking Skill and Students' Character. Al-Ta Lim Journal, 23(3), 224. https://doi.org/10.15548/jt.v23i3.244

Asyhari, A., \& Hartati, R. (2015). Implementasi Pembelajaran Fisika SMA Berbasis Inkuiri Terbimbing Terintegrasi Pendidikan Karakter untuk Meningkatkan Hasil Belajar Siswa pada Materi Cahaya dan Optika. Jurnal Ilmiah Pendidikan Fisika Al-Biruni, 4(1), 37-49.

Bell, T., Urhahne, D., \& Schanze, S. (2013). Collaborative Inquiry Learning: Models, tools, and challenges. International Journal of Science Education, 32(3), 349-377. https://doi.org/https://doi.org/10.108 0/09500690802582241

Dewi, P. S. (2016). Perspektif Guru sebagai Implementasi Pembelajaran Inkuiri Terbuka dan Inkuiri Terbimbing terhadap Sikap Ilmiah dalam Pembelajaran Sains. Tadris: Jurnal Keguruan Dan Ilmu Tarbiyah, 1(2), 179-186.

Diana Putri, S., \& Djamas, D. (2017). Pengembangan Perangkat Pembelajaran Fisika Berbasis Keterampilan Berpikir Kritis dalam Problem-Based Learning. Jurnal Ilmiah Pendidikan Fisika Al-Biruni, $6(1)$, 125-135. https://doi.org/https://doi.org/10.240 42/jpifalbiruni.v6i1.648

Inzanah, Ibrahim, M., \& Widodo, W. (2014). Pengembangan Perangkat Pembelajaran IPA Berbasis Kurikulum 2013 untuk Melatih Literasi Sains Siswa SMP.
Pendidikan Sains Pascasarjana Universitas Negeri Surabaya, 4(1), 549-567.

Lastriningsih, L. (2017). Peningkatan Berpikir Kritis dan Prestasi Belajar Melalui Metode Inquiry pada Siswa Kelas IV SD. Jurnal Prima Edukasia, 5(1), 68-78.

Latifah, S. (2015). Pengaruh Model Pembelajaran Kooperatif Tipe Time Token Berbantu Puzzle terhadap Kemampuan Berpikir Kritis Peserta Didik Kelas X pada Materi Gelombang. Jurnal Ilmiah Pendidikan Fisika Al-Biruni, 4(1), 13-23.

Maulida, D. R., \& Kusumaningtyas, D. A. (2017). Efektivitas Kegiatan Praktikum terhadap Hasil Belajar Fisika Kelas X pada Materi Asas Black di SMA Muhammadiyah 4 Yogyakarta Tahun Ajaran 2015 / 2016. Jurnal Penelitian \& Pengembangan Pendidikan Fisika, 3(1), 43-48.

Nisa', A., Sudarmin, \& Samini. (2015). Efektivitas Penggunaan Modul Terintegrasi Etnosains dalam Pembelajaran Berbasis Masalah untuk Meningkatkan Literasi Sains. Unnes Science Education Journal, 4(3), 1049-1056.

Nuriyatin, S., \& Hartono, H. (2016). Pengembangan Pembelajaran Penemuan Terbimbing untuk Meningkatkan Berpikir Kritis dan Motivasi Belajar Geometri di SMP. PYTHAGORAS: Jurnal Pendidikan Matematika, 11(2), 207-218. https://doi.org/https://doi.org/10.218 31/PG.V11I2.10656

Popescu, A., \& Morgan, J. (2007). Teaching Information Evaluation and Critical Thinking Skills in Physics Classes. American Assosiation of Physics Teachers, 507(45), 507-510. https://doi.org/https://doi.org/10.111 9/1.2798365

Rokhimi, I. N., \& Pujayanto. (2015). Alat 
Peraga Pembelajaran Laju Hantaran Kalor Konduksi. Prosiding Seminar Nasional Fisika Dan Pendidikan Fisika (SNFPF), 6, 270-274.

Saregar, A., Marlina, A., \& Kholid, I. (2017). Efektivitas Model Pembelajaran ARIAS ditinjau dari Sikap Ilmiah: Dampak terhadap Pemahaman Konsep Fluida Statis. Jurnal Ilmiah Pendidikan Fisika AlBiruni, 6(2), 255-263. https://doi.org/10.24042/jipfalbiruni. v6i2.2181 